\title{
Molecular Beacons: A New Approach to Plant Virus Detection
}

\author{
Alvin Jin-Cherng Eun and Sek-Man Wong
}

Department of Biological Sciences, National University of Singapore, Kent Ridge, Singapore 117543.

Accepted for publication 24 November 1999.

\begin{abstract}
Eun, A. J.-C., and Wong, S.-M. 2000. Molecular beacons: A new approach to plant virus detection. Phytopathology 90:269-275.

Molecular beacons are single-stranded nucleic acid molecules with a stem-loop conformation. The stem portion consists of complementary sequences at the $5^{\prime}$ and $3^{\prime}$ terminals of the molecule, while the loop portion consists of probe sequences that are complementary to the target sequences of choice. A fluorescent moiety is attached to one end, while a quenching moiety is attached to the opposite end. Reverse transcriptionpolymerase chain reactions are carried out with primers that amplify specific genome sequences of interest, yielding targets complementary to their

respective molecular beacons for subsequent detection. Here, we have designed four molecular beacons specific to the RNA-dependent RNA polymerase and coat protein genes of two orchid viruses, namely Cymbidium mosaic virus (CymMV) and Odontoglossum ringspot virus (ORSV). This technology is successfully applied to detect as little as $0.5 \mathrm{ng}$ of viral RNA of both orchid viruses simultaneously in $100 \mathrm{mg}$ of coinfected Oncidium orchid leaves. This rapid and specific technique is applicable to the orchid industry, which routinely carries out virus indexing and screening for virus-resistant cultivars. We belief that use of this molecular beacon approach can be extended to the detection of multiple plant viruses in various crops.
\end{abstract}

A novel fluorescence-based nucleic acid detection technique was developed by Tyagi and Kramer in 1996 (17). The probe, which is termed a molecular beacon, consists of a single-stranded DNA with a stem-loop structure (Fig. 1A). The loop portion consists of a probe sequence that is complementary to a target sequence. The stem portion is formed by the annealing of the $5^{\prime}$ and $3^{\prime}$ arm sequences, which are unrelated to the target sequence. A fluorescent moiety is attached to the $5^{\prime}$ arm terminus, while a quenching moiety is attached to the $3^{\prime}$ arm at the opposite end. The molecular beacon is added to a solution to be tested for the presence of the target nucleic acid. The mixture is heated to $80^{\circ} \mathrm{C}$ and then allowed to cool to $20^{\circ} \mathrm{C}$. The fluorescence intensity is monitored continuously during the entire period. In the absence of a target, the arms associate to form a stem-loop conformation. The fluorescence emitted from the fluorophore is quenched by fluorescence resonance energy transfer via the quencher due to their close proximity to each other (Fig. 1A). In the presence of a target, the probe forms a hybrid with the target via its complementary sequence within the loop region, resulting in the displacement of the fluorescent moiety from the quenching moiety, thus resulting in fluorescence emission (Fig. 1B). The molecular beacons emit fluorescent signals only upon hybridization with their complementary target nucleic acids. Since unhybridized molecular beacons do not fluoresce, it is not necessary to remove them from the reaction mixture.

Multiple molecular beacons can be employed in a single reaction tube (16). This is feasible, since each molecular beacon could be tagged with fluorescent moieties that possess different emission wavelengths. Here, we describe the application of two pairs of molecular beacons for the detection of the two most prevalent orchid viruses, namely Cymbidium mosaic virus (CymMV), in the genus Potexvirus, and Odontoglossum ringspot virus (ORSV), in the genus Tobamovirus, in infected orchid leaf tissues. The first pair was designed to detect the RNA-dependent RNA polymerase (RdRp) genes, while the second pair was used to detect the coat protein (CP) genes of both CymMV and ORSV simultaneously

Corresponding author: S.-M. Wong; E-mail address: dbswsm@nus.edu.sg

Publication no. P-2000-0117-02R

(C) 2000 The American Phytopathological Society
(Fig. 2A and B). Reverse transcription-polymerase chain reactions (RT-PCR) using four primer pairs were performed to amplify the genome targets from total RNA extracted from CymMV-and-ORSVcoinfected Oncidium orchid leaves (Fig. 2A and B) prior to hybridization of the molecular beacons. To differentiate the two viruses, molecular beacons specific to CymMV were tagged with 6-carboxyfluorescein (FAM), while those specific to ORSV were tagged with tetra-chloro-6-carboxyfluorescein (TET). To serve as the universal quenching moiety, 6-carboxy-tetramethyl-rhodamine (TAMRA) was attached to the $3^{\prime}$ ends of all four molecular beacons.

Both CymMV and ORSV have attained a worldwide distribution, infecting numerous commercially important orchid genera (18, 20). As such, many diagnostic techniques have been developed over the years for their detection. RT-PCR has been used for the detection of CymMV $(7,12)$ and ORSV (11). Detection via immunocapture-PCR of both viruses in orchids has also been successfully developed (1). More recent techniques have been developed to detect both orchid viruses using digoxigenin (DIG)-labeled cRNA probes (6), simultaneous touchdown (TD) RT-PCR with a single primer pair (15), and immuno-capillary zone electrophoresis (ICZE) (3). Here, we report the successful application of molecular beacons to detect CymMV and ORSV simultaneously. In addition, we compared the detection sensitivity of two sets of molecular beacons that were targeted to the RdRp and $\mathrm{CP}$ genes, respectively. This novel technology provides great application potential to virus detection, and its use can be extended to the detection of multiple viruses in various crop plants.

\section{MATERIALS AND METHODS}

Molecular beacons design. Several factors were considered when we designed the molecular beacons. The lengths of the molecular beacons were chosen so as to maximize the separation between the fluorophore and the quencher when the probes are hybridized to their respective targets. A sequence of 35 nucleotides, inclusive of the $3^{\prime}$ and $5^{\prime}$ stem portions, was chosen for all four molecular beacons. The open arms of these beacons were constructed in a trans configuration in relation to the probe-target helix upon hybridization, i.e., the fluorophore and quencher are on opposite sides of each other along the helical hybrid molecule. The 
stem region was designed such that its melting point $\left(\mathrm{T}_{m}\right)$ was lower than that of the loop-target region based on base pair number and composition. Different fluorescent moieties were attached to each molecular beacon pair for the detection of RdRp and CP genes. FAM (excitation wavelength $=494 \mathrm{~nm}$, emission wavelength $=521 \mathrm{~nm}$ ) was attached to the $5^{\prime}$ ends of the molecular beacons specific to CymMV genes (MCM-RdRp and MCM-CP), whereas TET (excitation wavelength $=519 \mathrm{~nm}$, emission wavelength $=537 \mathrm{~nm}$ ) was attached to the $5^{\prime}$ ends of the molecular beacons specific to ORSV genes (MOR-RdRp and MOR-CP) (Table 1). TAMRA was attached to the $3^{\prime}$ ends of all four molecular bea- cons to serve as the universal quenching moiety. All molecular beacons were synthesized by the Midland Certified Reagent Company, Midland, TX.

Thermal denaturation profiles of the molecular beacons. Four synthetic targets (TCM-RdRp, TCM-CP, TOR-RdRp, and TOR-CP) (Table 1) were synthesized (Genset Oligos, Singapore) such that they are perfectly complementary to their respective molecular beacon loops (MCM-RdRp, MCM-CP, MOR-RdRp, and MOR-CP, respectively). The concentration of molecular beacons used throughout all experiments was $200 \mathrm{nM}$. The synthetic targets were used to determine the thermal denaturation profiles as
A

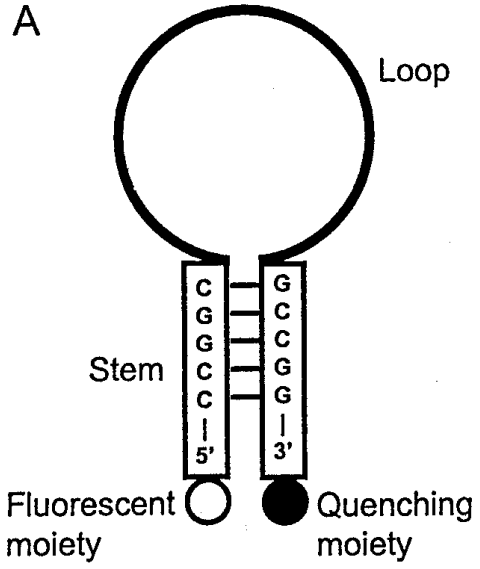

B

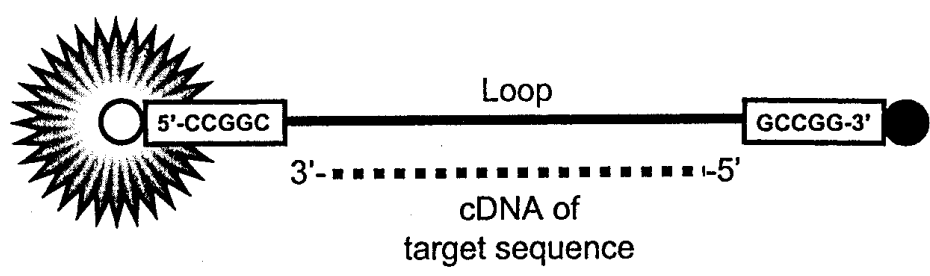

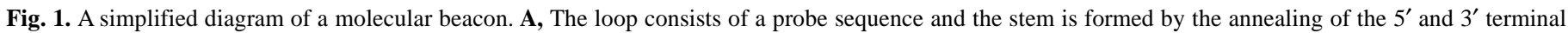

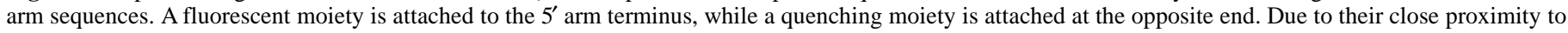

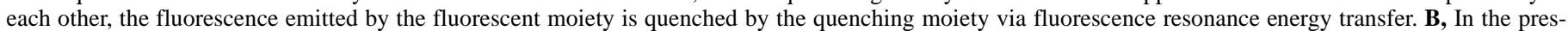

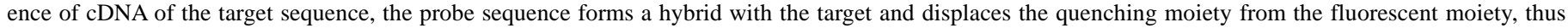
allowing fluorescence.

\section{A CymMV}

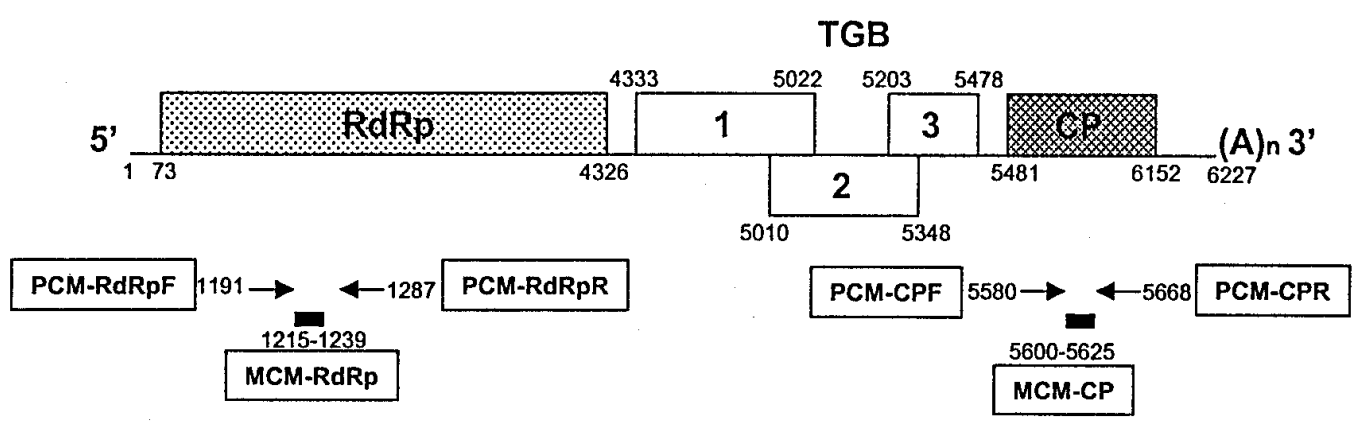

B ORSV

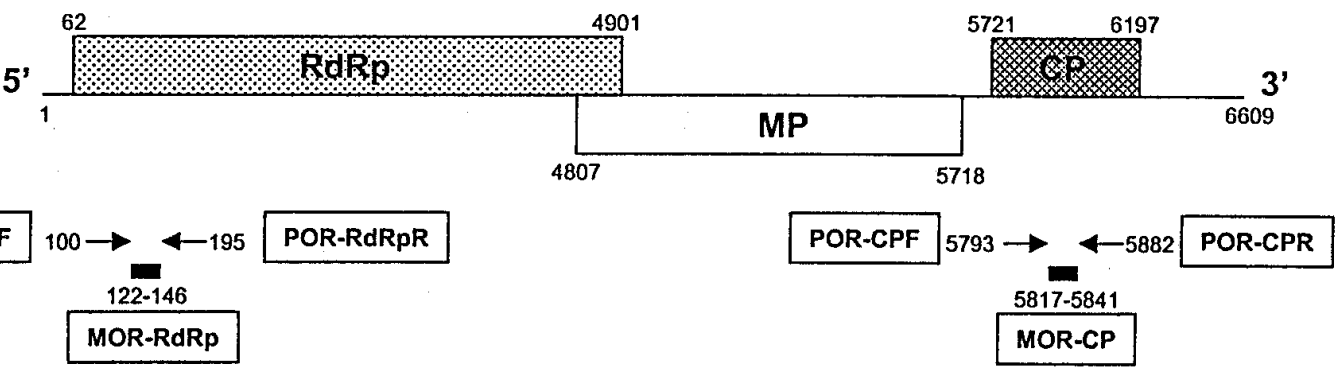

Fig. 2. The genome organization of A, Cymbidium mosaic virus (CymMV) and B, Odontoglossum ringspot virus (ORSV) showing RNA-dependent RNA polymerase (RdRp); triple gene blocks (TGB) 1, 2, and 3; movement protein (MP); and coat protein (CP). The positions of four pairs of reverse transcription-polymerase chain reaction primers (PCM-RdRpF and PCM-RdRpR, PCM-CPF and PCM-CPR, POR-RdRpF and POR-RdRpR, and POR-CPF and POR-CPR) and four molecular beacons (MCM-RdRp, MCM-CP, MOR-RdRp, and MOR-CP) are indicated $(2,19)$. 
well as to test the specificity of the molecular beacons. For the thermal denaturation profile of each molecular beacon, two tubes, each containing $50 \mu \mathrm{l}$ of $200 \mathrm{nM}$ molecular beacon in $3.5 \mathrm{mM}$ $\mathrm{MgCl}_{2}$ and $10 \mathrm{mM}$ Tris-HCl, $\mathrm{pH} 8.0$, were prepared. An excess amount of the respective target (diluted in 1× Tris-EDTA, pH 8.0, to a concentration of $400 \mathrm{nM}$ ) was added into one of the tubes, while an equal volume of $1 \times$ Tris-EDTA, $\mathrm{pH} 8.0$, was added into the second tube. The tubes were placed in a plastic 96-well holding rack and inserted into the thermocycling block of the ABI Prism 7700 Sequence Detector (Applied Biosystems, Inc., Foster City, CA). The lid of the Sequence Detector, which incorporates the fluorescence detection mechanisms, was subsequently tightened, the tubes heated to $80^{\circ} \mathrm{C}$, and the temperature decreased to $20^{\circ} \mathrm{C}$ at the rate of $1{ }^{\circ} \mathrm{C} / \mathrm{min}$. The fluorescence intensities of both the reporter dye (FAM or TET) and the quencher dye (TAMRA) were monitored throughout the amplification process over real time by the Sequence Detector. The normalized reporter signal $(\Delta \mathrm{Rn})$ was calculated by the built-in software using the equation $\Delta R n=$ $\mathrm{Rn}^{+}-\mathrm{Rn}^{-}$, in which $\mathrm{Rn}^{+}$is the division of the emission intensity of the reporter by the emission intensity of the quencher at any given time in a reaction tube, while $\mathrm{Rn}^{-}$is the division of the emission intensity of the reporter by the emission intensity of the quencher measured prior to RT-PCR amplification in that same reaction tube. For the purpose of quantification, the last three data points collected during the extension step for each RT-PCR cycle were averaged. The mean $\Delta \mathrm{Rn}$ value for each RT-PCR was used to plot the amplification graphs. All experiments were repeated at least three times.

Molecular beacon specificity. For the determination of molecular beacon specificity, four tubes were prepared, each containing all four molecular beacons at concentrations of $200 \mathrm{nM}$. Each synthetic target (TCM-RdRp, TCM-CP, TOR-RdRp, and TOR-CP) was diluted in $1 \times$ Tris-EDTA, $\mathrm{pH} 8.0$, to a concentration of $400 \mathrm{nM}$ and added to separate reactions tubes to determine the specificity of their corresponding molecular beacons (MCM-RdRp, MCM$\mathrm{CP}, \mathrm{MOR}-\mathrm{RdRp}$, and MOR-CP, respectively). The tubes were initially heated to $80^{\circ} \mathrm{C}$ and the temperature decreased to $15^{\circ} \mathrm{C}$ at $1^{\circ} \mathrm{C} / \mathrm{min}$ for fluorescence detection. All experiments were repeated at least three times.

CymMV and ORSV RNA purification. CymMV and ORSV were propagated and purified as previously described (3). An aliquot containing $5 \mathrm{mg}$ of purified virus was vortexed for $10 \mathrm{~min}$ with $290 \mu \mathrm{l}$ of $0.01 \mathrm{M}$ sodium borate buffer, $\mathrm{pH} 7.5$; $300 \mu \mathrm{l}$ of RNA extraction buffer (20\% Tris, $20 \% \mathrm{NaCl}, 10 \%$ sodium dodecyl sul- fate, and $0.4 \%$ EDTA); and $600 \mu \mathrm{l}$ of water-saturated phenol/chloroform (1:1) mixture. After low-speed centrifugation at 13,000 $\times g$ for $10 \mathrm{~min}$ at $4{ }^{\circ} \mathrm{C}$, the aqueous phase was reextracted with phenol/ chloroform and subsequently with $300 \mu \mathrm{l}$ of chloroform. The aqueous phase was collected and the RNA precipitated with ethanol. The purified RNA was quantified spectrophotometrically and stored at $-80^{\circ} \mathrm{C}$

Detection sensitivity of the molecular beacons. Purified CymMV and ORSV RNA were serially diluted in order to determine the detection sensitivity of the molecular beacons. The amounts of RNA analyzed were $0.01,0.5,1.0,2.0$, and $5.0 \mathrm{ng}$ suspended in nuclease-free water. For the negative control, no RNA templates were added. Four primer pairs were synthesized (PCM-RdRpF and PCM-RdRpR, PCM-CPF and PCM-CPR, POR-RdRpF and PORRdRpR, and POR-CPF and POR-CPR) (Table 1). Each primer pair specifically amplified the segment of viral gene to be detected by its complementary molecular beacon (Fig. 2A and B). The RT-PCR reaction mix contained purified RNA, $10 \mu \mathrm{l}$ of Avian myeloblastosis virus (AMV)/Thermus flavus (Tfl) $5 \times$ reaction buffer, $10 \mathrm{mM}$ of each dNTP, 15 pmol of upstream primers, 45 pmol of downstream primer, $25 \mathrm{mM} \mathrm{MgSO}$, and 5 units each of AMV reverse transcriptase and Tfl DNA polymerase (Promega Corp., Madison, WI). The final reaction volume was increased to $50 \mu \mathrm{l}$ with nuclease-free water. The thermal cycling parameters employed were as follows: reverse transcription at $48^{\circ} \mathrm{C}$ for $45 \mathrm{~min}$, DNA denaturation at $94^{\circ} \mathrm{C}$ for $2 \mathrm{~min}, 40$ cycles of TD-PCR at $94^{\circ} \mathrm{C}$ for $1 \mathrm{~min}$, annealing at $55^{\circ} \mathrm{C}$ for $1 \mathrm{~min}$ at a $0.5^{\circ} \mathrm{C}$ decrease per cycle, extension at $68^{\circ} \mathrm{C}$ for $1 \mathrm{~min}$, and a final extension at $68^{\circ} \mathrm{C}$ for $5 \mathrm{~min}$. The RT-PCR products $(10 \mu \mathrm{l})$ were added to $50 \mu \mathrm{l}$ of $200 \mathrm{nM}$ molecular beacon dissolved in $3.5 \mathrm{mM} \mathrm{MgCl}_{2}$ and $10 \mathrm{mM}$ Tris- $\mathrm{HCl}, \mathrm{pH}$ 8.0. The tubes were initially heated to $80^{\circ} \mathrm{C}$ and the temperature then decreased to $20^{\circ} \mathrm{C}$ at $1{ }^{\circ} \mathrm{C} / \mathrm{min}$. The fluorescence intensity at room temperature $\left(25^{\circ} \mathrm{C}\right)$ between various concentrations of RNA was recorded. All experiments were repeated at least three times.

Simultaneous detection of CymMV and ORSV. Total RNA was extracted from $100 \mathrm{mg}$ of CymMV-and-ORSV-coinfected Oncidium orchid leaves (Qiagen RNeasy Plant Kit; Qiagen, Hilden, Germany). An equal amount of total RNA was extracted from noninfected orchid leaves for use as a negative control. Two pairs of tubes were prepared for the simultaneous detection of viral RdRp and CP genes; each pair had one tube containing $10 \mathrm{ng}$ of total RNA from virus-infected Oncidium leaves and a second tube containing an equal amount of total RNA from healthy orchid leaves. Simultaneous detection of the RdRp genes of CymMV and ORSV

TABLE 1. Sequences of the molecular beacons, synthetic targets, and reverse transcription-polymerase chain reaction (RT-PCR) primers ${ }^{\mathrm{a}}$

\begin{tabular}{|c|c|c|}
\hline & Abbreviation & Sequence $^{b}$ \\
\hline \multicolumn{3}{|l|}{ Molecular beacons } \\
\hline \multirow{2}{*}{ RdRp detection } & MCM-RdRp & 5'-FAM-CCAGCTTGGTCCGCTCCGGTGAATAGTTGGGCTGG-TAMRA-3 \\
\hline & MOR-RdRp & 5'-TET-CCAGCCTGAGCCAAATCGTTAATGAGGCTGGCTGG-TAMRA-3' \\
\hline $\mathrm{CP}$ detection & MOR-CP & 5'-TET-CCAGCCTTGTTGTGTTTGGAACTGATTACCGCTGG-TAMRA-3' \\
\hline \multicolumn{3}{|l|}{ Synthetic targets } \\
\hline RdRp detection & TCM-RdRp & 5'-CCAACTATTCACCGGAGCGGACCAA-3' \\
\hline \multicolumn{3}{|l|}{ RT-PCR primers } \\
\hline \multirow[t]{4}{*}{ RdRp detection } & PCM-RdRpF & 5'-CAAGAACAAGATACGGGAATTGG-3' \\
\hline & PCM-RdRpR & 5'-TCGAGAGCTTTGAGCAGTTGATT-3' \\
\hline & POR-RdRpF & $5^{\prime}$-TTGAGGCTGGTATGGGCAG-3' \\
\hline & POR-RdRpR & $5^{\prime}$-TTCGACAGCGTTATCGTAAACAC-3' \\
\hline $\mathrm{CP}$ detection & PCM-CPF & 5'-TCACCTCCTCCATCGCCA-3' \\
\hline
\end{tabular}

\footnotetext{
${ }^{a} \mathrm{RdRp}=\mathrm{RNA}-$ dependent RNA polymerase, $\mathrm{CP}=$ coat protein, $\mathrm{FAM}=$ 6-carboxyfluorescein, TET = tetra-chloro-6-carboxyfluorescein, and TAMRA = 6-carboxytetramethyl-rhodamine.

${ }^{\mathrm{b}}$ Underlined sequences represent the $5^{\prime}$ and $3^{\prime}$ arm sequences of the molecular beacons that form the stem portion.
} 
was performed. Two primer pairs (PCM-RdRpF and PCM-RdRpR, and POR-RdRpF and POR-RdRpR) were added to a 50- $\mu$ l RTPCR mix, and 40 cycles of TD-PCR were carried out as described before. Subsequently, the two CymMV and ORSV molecular beacons of RdRp (MCM-RdRp and MOR-RdRp, respectively) were added to the reaction tube for the detection of both $\mathrm{RdRp}$ genes. The thermal denaturation profiles were plotted. This was made possible since the molecular beacons were tagged with two fluorescent moieties of different emission wavelengths. Here, FAM was tagged to CymMV and TET was tagged to ORSV. Similarly, simultaneous detection of CymMV and ORSV CP genes was carried out using their respective primer pairs (PCM-CPF and PCM-CPR, and POR-CPF and POR-CPR) and molecular beacons (MCM-CP and MOR-CP). All experiments were repeated at least three times.

\section{RESULTS}

Thermal denaturation profiles of the molecular beacons. The thermal denaturation profiles of the four molecular beacons (Fig. 3A to D) resembled those reported previously $(4,10)$. There was a significant increase in fluorescence intensity in tubes containing both the molecular beacon and its respective synthetic target as the temperature was decreased from 80 to $20^{\circ} \mathrm{C}$. For MCM-RdRp (Fig. 3A) and MCM-CP (Fig. 3B), the fluorescence intensity increased gradually to a maximum of 7,900 and 4,500 fluorescence units, respectively. For MOR-RdRp (Fig. 3C) and MOR-CP (Fig. $3 \mathrm{D}$ ), the fluorescence intensity increased to a maximum of 4,700 and 3,700 fluorescence units, respectively. In tubes containing only the molecular beacons, the fluorescence intensity remained at a baseline level.

Molecular beacon specificity. Only when the complementary targets were added to the molecular beacons could an increase in fluorescence intensity be detected. For MCM-RdRp (Fig. 4A) and MCM-CP (Fig. 4B), the fluorescence intensity increased gradually to a maxim of 8,100 and 4,500 fluorescence units, respectively. For MOR-RdRp (Fig. 4C) and MOR-CP (Fig. 4D), the fluorescence intensity increased to a maximum of 4,700 and 3,700 fluorescence units, respectively. The fluorescence intensity of the molecular beacons whose probe sequence was not complementary to target sequence (control treatments) exhibited only a baseline level of fluorescence.

Detection sensitivity of the molecular beacons. The molecular beacons were able to detect down to $0.5 \mathrm{ng}$ of both CymMV and ORSV purified RNA. The fluorescence intensity of the various quantities of RNA was analyzed at a room temperature of $25^{\circ} \mathrm{C}$ (Fig. 5). The molecular beacons specific to the RdRp genes (MCMRdRp and MOR-RdRp) yielded higher maximum fluorescence intensities as compared with those specific to the CP genes (e.g., when $5 \mathrm{ng}$ of purified RNA was used, MCM-RdRp and MOR-RdRp yielded 9,000 and 6,000 fluorescence units, respectively, while MCM-CP and MOR-CP yielded 4,800 and 3,500 fluorescence units, respectively) (Fig. 5). Fluorescence intensity also increased as the initial amount of viral RNA used was increased. Using this technique, as little as $0.5 \mathrm{ng}$ of viral RNA was detectable via all four molecular beacons after RT-PCR amplification.

Simultaneous detection of CymMV and ORSV. The thermal dissociation graphs of the molecular beacons with their associated samples were obtained (Fig. 6A and B). Only tubes containing total RNA isolated from CymMV-and-ORSV-coinfected Oncidium leaves yielded significant increases in fluorescence intensities upon the addition of both sets of molecular beacons: MCM-RdRp and MOR-RdRp for simultaneous RdRp gene nucleotide sequence detection and MCM-CP and MOR-CP for simultaneous CP gene nucleotide sequence detection. For MCM-RdRp and MOR-RdRp, the fluorescence intensities increased to a maximum of 8,500 and 4,200 fluorescence units, respectively. For MCM-CP and MOR$\mathrm{CP}$, the fluorescence intensities increased to a maximum of 4,000 and 3,100 fluorescence units, respectively. The fluorescence in-
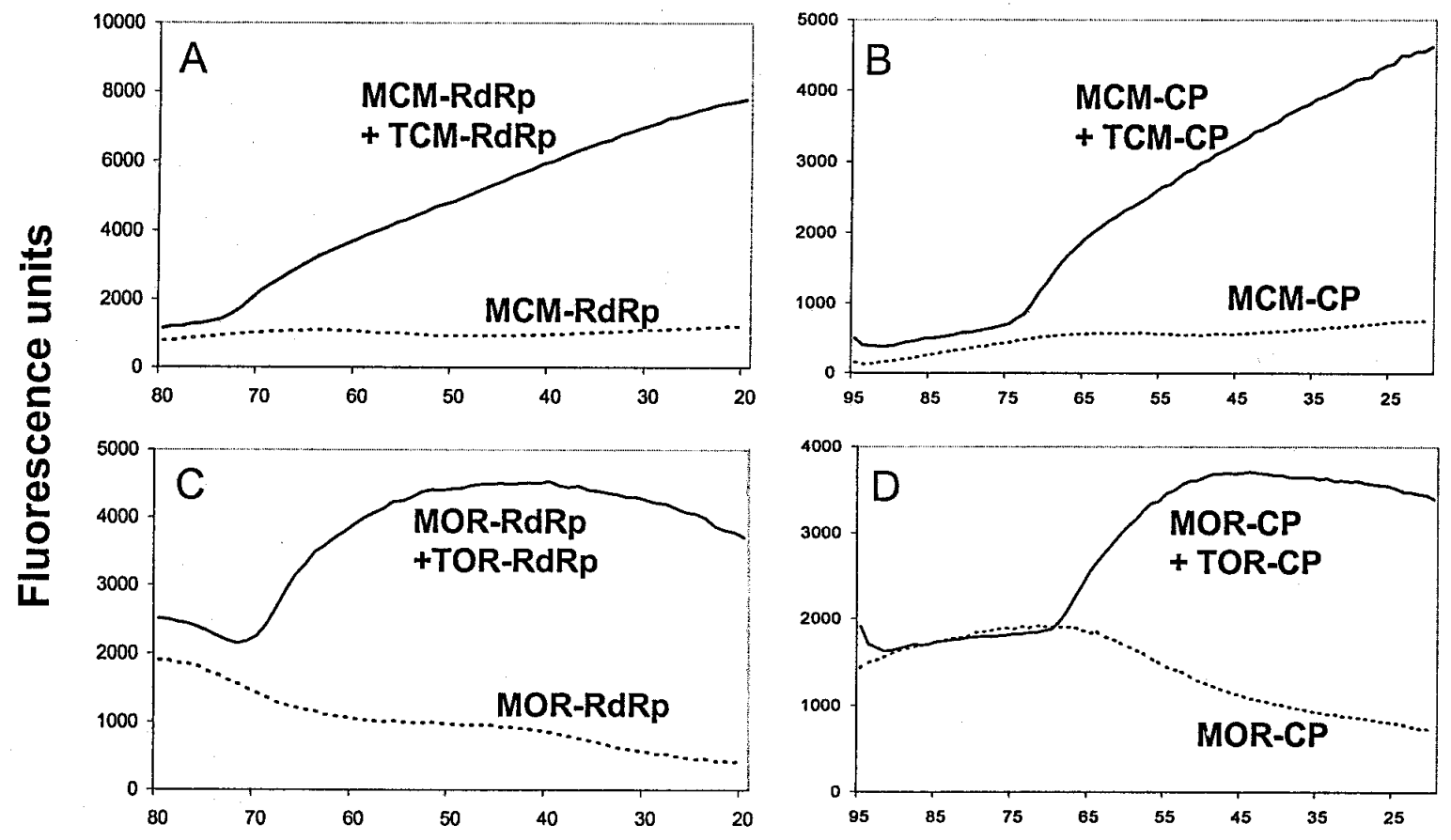

\section{Temperature $\left({ }^{\circ} \mathrm{C}\right)$}

Fig. 3. Thermal denaturation profiles of four molecular beacons (MCM-RdRp, MCM-CP, MOR-RdRp, and MOR-CP) with their respective synthetic targets (TCM-RdRp, TCM-CP, TOR-RdRp, and TOR-CP). Note the significant increase in fluorescence intensity in tubes containing both the molecular beacon and its respective synthetic target as the temperature was decreased from 80 to $20^{\circ} \mathrm{C}$. For $\mathbf{A}, \mathrm{MCM}-\mathrm{RdRp}$ and $\mathbf{B}, \mathrm{MCM}-\mathrm{CP}$, the fluorescence intensity increased gradually to a maximum of 7,900 and 4,500 fluorescence units, respectively. For C, MOR-RdRp and D, MOR-CP, the fluorescence intensity increased to a maximum of 4,700 and 3,700 fluorescence units, respectively. In tubes containing only the molecular beacons, the fluorescence intensity remained at a low baseline level. 
tensities of the molecular beacons (MCM-RdRp, MCM-CP, MOR$\mathrm{RdRp}$, and MOR-CP) in the presence of healthy orchid leaf total RNA remained at a low baseline level of fluorescence intensity.

\section{DISCUSSION}

Since the invention of the molecular beacon technology, it has been used for identification of bacteria (Ruminococcus albus and Fibrobacter succinogenes) (14), detection of drug resistance in Mycobacterium tuberculosis (10), mutation of the methylenetetra- hydrofolate reductase (MTHFR) gene (4), identification of differential expression genes (8), and multiplex detection of single-nucleotide variations (9) in M. tuberculosis. Here, we show that molecular beacons can be used to detect two orchid viruses simultaneously.

As the temperature was increased initially, the molecular beacons and target molecules were denatured. At higher temperatures, there was fluorescence regardless of the presence of their complementary targets, since the fluorescent moieties were displaced from the quenching moieties due to the absence of the stemloop. As the temperature was lowered to the melting temperature
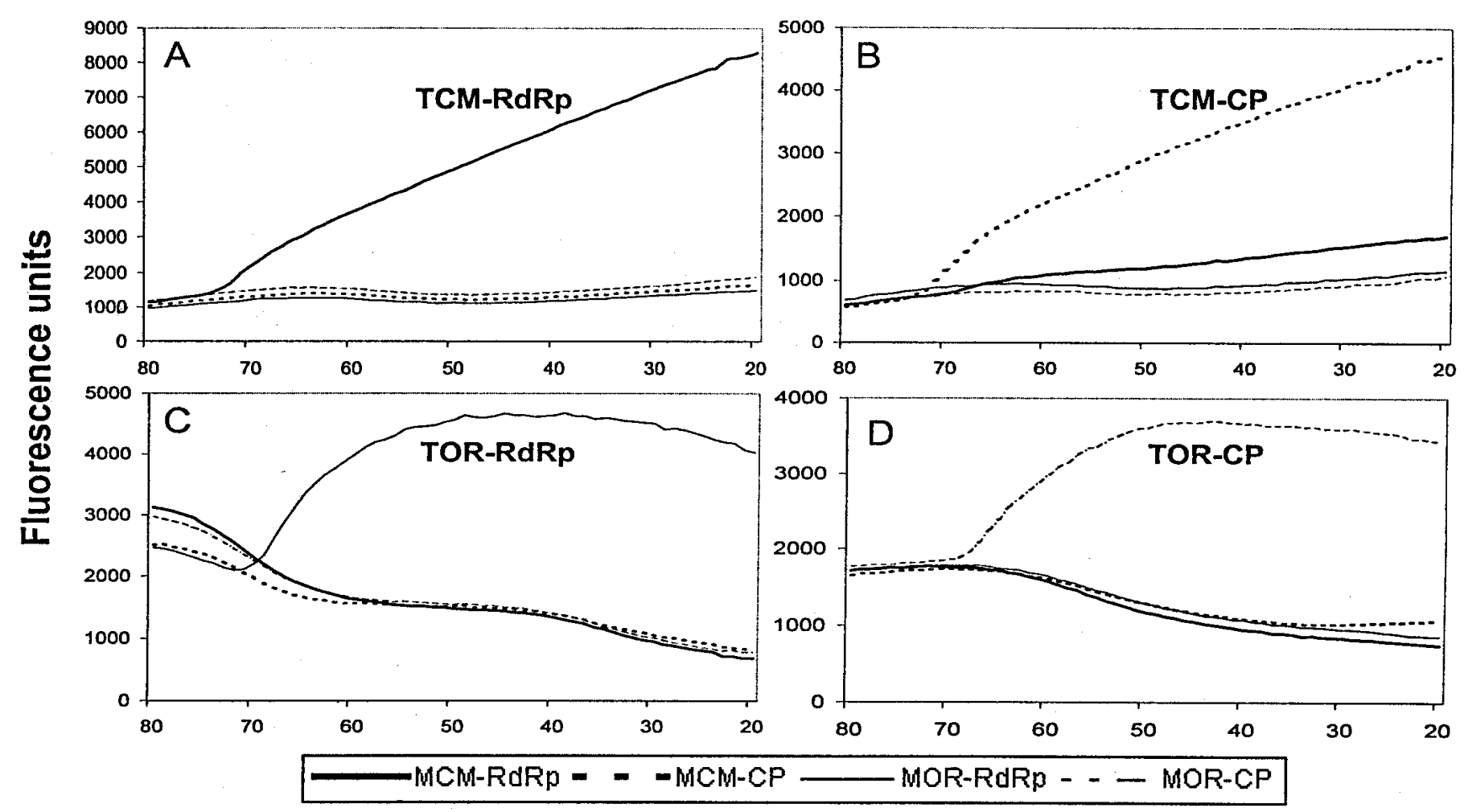

\section{Temperature $\left({ }^{\circ} \mathrm{C}\right)$}

Fig. 4. Molecular beacon specificity. Only when complementary targets were added to the molecular beacon was there an increase in fluorescence intensity. For A, MCM-RdRp and B, MCM-CP, the fluorescence intensity increased gradually to a maximum of 8,100 and 4,500 fluorescence units, respectively. For C, MOR-RdRp and D, MOR-CP, the fluorescence intensity increased to a maximum of 4,700 and 3,700 fluorescence units, respectively. The fluorescence intensity of the molecular beacons remained at a low baseline level when probe sequences were not complementary to the added target sequences.

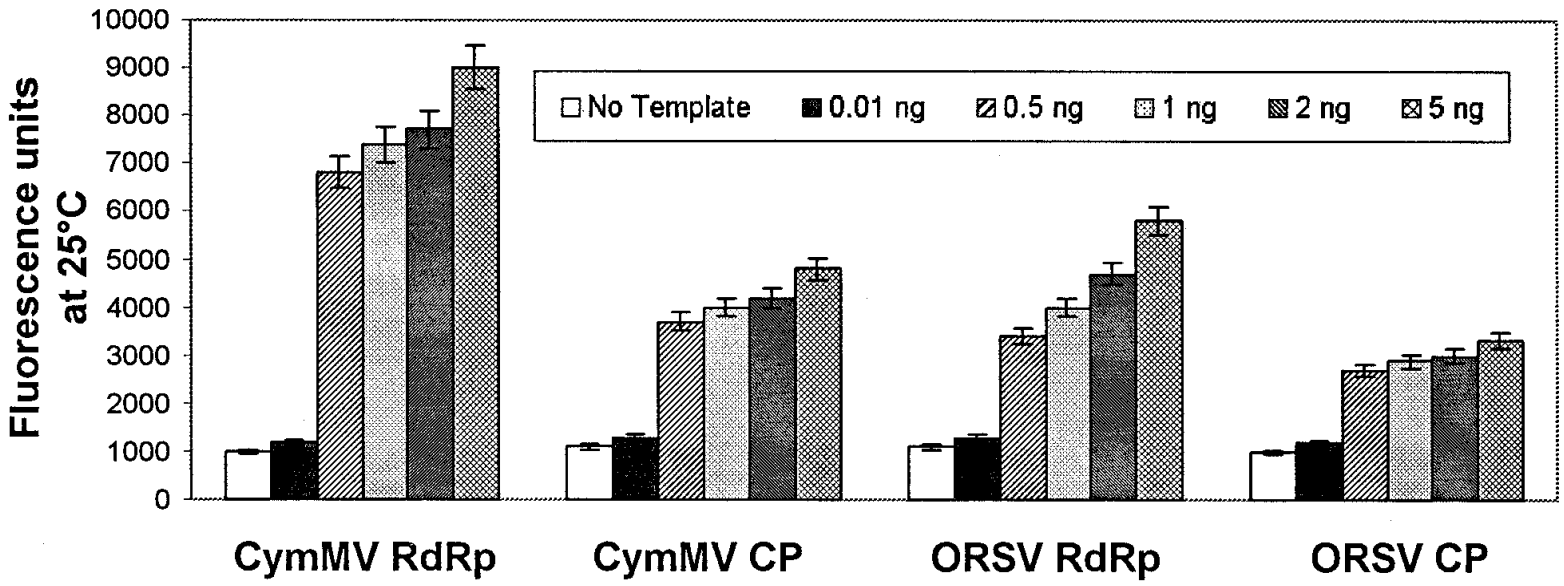

Fig. 5. Detection sensitivity of the molecular beacons. The fluorescence intensity of all molecular beacons increased drastically when $0.5,1,2$, and 5 ng of purified viral RNA were tested. The lowest detection sensitivity was $0.5 \mathrm{ng}$ of purified viral RNA. 
$\left(\mathrm{T}_{m}\right)$ of the molecular beacon-target hybrid, these two entities annealed and displaced the fluorescent moiety from the quenching moiety. The thermal denaturation profiles of the four molecular beacons differ from each other because of the different probe sequences. The $\mathrm{T}_{m}$ of a molecular beacon depends upon the length of its stem hybrid, the G-C content of the arm sequence, and the concentration of the salts in the reaction solution (17). These factors have been optimized with the aid of the built-in Sequence Detector software (data not shown) and kept constant in all our experiments. Identical arm sequences are used in all four molecular beacons, ensuring consistency in both stem hybrid length and their G-C content. All molecular beacons were dissolved in the same buffer. The only variable factor is the specific viral sequence in the loop region of each molecular beacon. In addition, the secondary structure of the complementary targets may limit the access of the molecular beacons. This has been minimized by initially heating the reaction mixture to $80^{\circ} \mathrm{C}$ in order to denature the complementary targets for easier annealing of their respective molecular beacons.

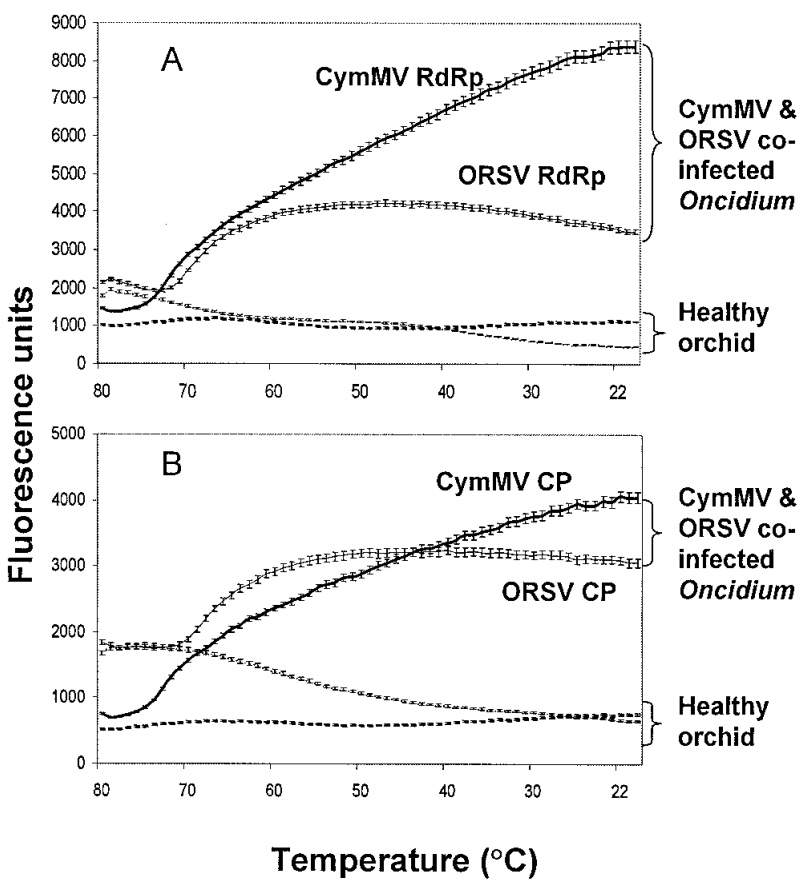

Fig. 6. Simultaneous detection of Cymbidium mosaic virus (CymMV) and Odontoglossum ringspot virus (ORSV). For all four molecular beacons, significant increase in fluorescence intensities occurred only in the presence of CymMV-and-ORSV-coinfected Oncidium orchid leaf tissue, but not with healthy leaf tissues. A, For MCM-RdRp and MOR-RdRp, the fluorescence intensities increased to a maximum of 8,500 and 4,200 fluorescence units, respectively. B, For MCM-CP and MOR-CP, the fluorescence intensities increased to a maximum of 4,000 and 3,100 fluorescence units, respectively. The fluorescence intensities of the molecular beacons (MCM-RdRp, MCM-CP, MOR-RdRp, and MOR-CP) remained at a low baseline level in the presence of healthy orchid leaf total RNA.
The molecular beacons were highly specific to their complementary targets. A molecular beacon "lit up" only in the presence of its complementary target and remained "dark" if its target was absent (Fig. 4A to D). The high specificity of the molecular beacons has been conclusively demonstrated $(9,10,16,17)$. Molecular beacons could discriminate even with one nucleotide mismatch (17). This high specificity is due to the presence of the stem-loop structure of the probes, as demonstrated by the comparison of such stem-loop probes with linear probes (14). The stem-loop provides two functions: it brings the fluorescent moiety close to the quenching moiety, such that there will be no emission of fluorescent signal in the absence of complementary targets, and it provides high specificity to the target sequence.

Molecular beacon technology offers many advantages over current methods for plant virus detection (Table 2). Since this method is new, the current cost per test is relatively high. The technology has a potential of becoming a preferred detection method because of its unique ability to detect specific viral genes in real time. Current nucleic acid detection involves immobilization of the nucleic acid samples onto a solid phase such as a nylon membrane, hybridization with a probe, and detection via colorimetric or chemiluminescent methods. Such methods entail removal of unhybridized probes to reduce background. Unhybridized molecular beacons revert back to their stem-loop conformation, thus suppressing fluorescence. This renders the removal of unhybridized molecular beacons unnecessary. Quantitative results can be obtained immediately, whereas other quantitative methods (e.g., RT-PCR and enzymelinked immunosorbent assay [ELISA]) require post-analysis detection steps such as gel electrophoresis or spectrophotometry. The ABI Prism 7700 Sequence Detector is able to obtain the results in real time as the reaction progresses. Although I-CZE offers the same real-time detection capability, it has a relatively low throughput of 10 min per sample. The molecular beacon technology offers 96-well simultaneous analysis, which is comparable to both RTPCR and ELISA.

The molecular beacon detection sensitivity is comparable to that of combined immunocapture and fluorogenic $5^{\prime}$ nuclease RT-PCR assay for the detection of Potato leafroll virus in dormant potato tubers (13). In addition, the molecular beacon detection method requires 10 times less starting material than does TD/RT-PCR (15). Although molecular beacon detection is not as sensitive as DIGlabeled cRNA probes, RT-PCR, or I-CZE, this method can be fully automated by incorporating a robotic sample preparation device and tubes predispensed with molecular beacons. This cuts down on the manual labor, which is needed with the conventional dot and northern blotting detection methods, and thus reduces human errors during experimentation. Analysis of the results is also more efficient since all the data are stored automatically in a computer; a computer software program can be created to identify positive reactions and provide a printout of the analysis results. The risk of contamination for the molecular beacons technology is kept to a minimal, since all the required probes and solutions are predispensed into sample tubes and no opening of the sample tubes is necessary once heating starts. This is possible since the real-time fluorescence analysis follows the reaction as it progresses. Other

TABLE 2. A comparison of some common methods of plant virus detection

\begin{tabular}{|c|c|c|c|c|c|c|c|c|}
\hline Method $^{\mathrm{a}}$ & $\begin{array}{c}\text { Real-time } \\
\text { analysis }\end{array}$ & Sensitivity & $\begin{array}{c}\text { Nature of } \\
\text { probe }\end{array}$ & $\begin{array}{l}\text { Relative cost } \\
\text { per sample } \\
\text { analyzed }\end{array}$ & $\begin{array}{c}\text { Speed } \\
\text { of analysis }\end{array}$ & $\begin{array}{c}\text { Ability to } \\
\text { detect } \\
\text { specific genes }\end{array}$ & Throughput & References \\
\hline Molecular beacons & Yes & $0.5 \mathrm{ng}$ & Nucl & High & $1 \mathrm{~h}$ for 96 & Yes & High (96 samples) & This study \\
\hline DIG-labeled cRNA probes & No & $100 \mathrm{pg}$ & Nucleic acid & Medium & $4 \mathrm{~h}$ for 1 sample & Yes & Medium (48 samples) & 6 \\
\hline RT-PCR & No & $100 \mathrm{fg}$ & Nucleic acid & Medium & $3.5 \mathrm{~h}$ for 96 samples & Yes & High (96 samples) & 15 \\
\hline ELISA & No & $2.5 \mathrm{ng}$ & Antibody & Low & $4 \mathrm{~h}$ for 96 samples & No & High (96 samples) & 5 \\
\hline
\end{tabular}

a I-CZE = immuno-capillary zone electrophoresis, DIG = digoxigenin, RT-PCR = reverse transcription-polymerase chain reaction, and ELISA = enzyme-linked immunosorbent assay. 
methods require the transfer of solutions or membranes from one apparatus to another, thus increasing the chances of cross-contamination.

With full automation of this system, the molecular beacon technique can provide a rapid and specific nucleic acid-based detection method for screening plants for virus-free certification, quarantine verification, germ plasm collection, and selection of disease-resistant plants. The use of this new approach also can be extended to the detection of multiple plant viruses in various crops.

\section{ACKNOWLEDGMENTS}

This work was supported by research grant RP 3972398 from the National University of Singapore (NUS), Republic of Singapore. A. J.-C. Eun is a recipient of a research scholarship from the NUS and the National Science and Technology Board (NSTB) Top-Up Scheme for graduate research in Biomedical Engineering. We thank S. Tyagi for his helpful suggestions on the setup of the Applied Biosystems ABI Prism 7700 Sequence Detector for molecular beacon application. We also thank S. A. Mudzakker of Perkin-Elmer Biosystems in Singapore for kindly allowing us to use the Applied Biosystems ABI Prism 7700 Sequence Detector.

\section{LITERATURE CITED}

1. Barry, K., Hu, J. S., Kuehnle, A. R., and Sughii, N. 1996. Sequence analysis and detection using immunocapture-PCR of cymbidium mosaic virus and odontoglossum ringspot virus in Hawaiian orchids. J. Phytopathol. 144:179-186.

2. Chng, C. G., Wong, S. M., Mathani, P. H., Loh, C. S., Goh, C. J., Kao, M. C. C., Chung, M. C. M., and Watanabe, Y. 1996. The complete sequence of a Singapore isolate of odontoglossum ringspot virus and comparison with other tobamoviruses. Gene 171:155-161.

3. Eun, A. J.-C., and Wong, S.-M. 1999. Detection of cymbidium mosaic potexvirus and odontoglossum ringspot tobamovirus using immuno-capillary zone electrophoresis. Phytopathology 89:522-528.

4. Giesendorf, B. A. J., Vet, J. A. M., Tyagi, S., Mensink, E. J. M. G., Trijbels, F. J. M., and Blom, H. J. 1998. Molecular beacons: A new approach for semiautomated mutation analysis. Clin. Chem. 44:482486.

5. Hill, J. H., Bryant, G. R., and Durand, D. P. 1981. Detection of plant virus by using purified IgG in ELISA. J. Virol. Methods 3:27-35.
6. Hu, W. W., and Wong, S. M. 1998. The use of DIG-labelled cRNA probes for the detection of cymbidium mosaic potexvirus (CymMV) and odontoglossum ringspot tobamovirus (ORSV) in orchids. J. Virol. Methods 70:193-199.

7. Lim, S. T., Wong, S. M., Yeong, C. Y., Lee, S. C., and Goh, C. J. 1993. Rapid detection of cymbidium mosaic virus by the polymerase chain reaction. J. Virol. Methods 41:37-46.

8. Manganelli, R., Dubnau, E., Tyagi, S., Kramer, F. R., and Smith, I. 1999. Differential expression of 10 sigma factor genes in Mycobacterium tuberculosis. Mol. Microbiol. 31:715-724.

9. Marras, S. A. E., Kramer, F. R., and Tyagi, S. 1999. Multiplex detection of single-nucleotide variations using molecular beacons. Genet. Anal. Biomol. Eng. 14:151-156.

10. Piatek, A. S., Tyagi, S., Pol, A. C., Telenti, A., Miller, L. P., Kramer, F. R., and Alland, D. 1998. Molecular beacon sequence analysis for detecting drug resistance in Mycobacterium tuberculosis. Nature Biotechnol. 16:359-363.

11. Ryu, K. H., and Park, W. M. 1995. Rapid detection and identification of odontoglossum ringspot virus by polymerase chain reaction amplification. FEMS Microbiol. Lett. 133:265-269.

12. Ryu, K. H., Yoon, K. E., and Park, W. M. 1995. Detection by RT-PCR of cymbidium mosaic virus in orchids. J. Phytopathol. 143:643-646.

13. Schoen, C. D., Knorr, D., and Leone, G. 1996. Detection of potato leafroll virus in dormant potato tubers by immunocapture and a fluorogenic 5' nuclease RT-PCR assay. Phytopathology 86:993-999.

14. Schofield, P., Pell, A. N., and Krause, D. O. 1997. Molecular beacons: Trial of a fluorescence-based solution hybridization technique for ecological studies with ruminal bacteria. Appl. Environ. Microbiol. 63:1143-1147.

15. Seoh, M. L., Wong, S. M., and Zhang, L. 1998. Simultaneous TD/RT-PCR detection of cymbidium mosaic potexvirus and odontoglossum ringspot tobamovirus with a single pair of primers. J. Virol. Methods 72:197-204.

16. Tyagi, S., Bratu, D. P., and Kramer, F. R. 1998. Multicolor molecular beacons for allele discrimination. Nature Biotechnol. 16:49-53.

17. Tyagi, S., and Kramer, F. R. 1996. Molecular beacons: Probes that fluoresce upon hybridization. Nature Biotechnol. 14:303-308.

18. Wong, S. M., Chng, C. G., Lee, Y. H., Tan, K., and Zettler, F. W. 1994. Incidence of cymbidium mosaic and odontoglossum ringspot viruses and their significance in orchid cultivation in Singapore. Crop Prot. 13:235-239.

19. Wong, S. M., Mathani, P. H., Lee, K. C., Yu, H. H., Tan, Y., Neo, K. K., Chan, Y., Wu, M., and Chng, C. G. 1997. Cymbidium mosaic potexvirus RNA: Complete nucleotide sequence and phylogenetic analysis. Arch. Virol. 142:383-391.

20. Zettler, F. W., Ko, N.-J., Wisler, G. C., Elliott, M. S., and Wong, S.-M. 1990. Viruses of orchids and their control. Plant Dis. 74:621-626. 